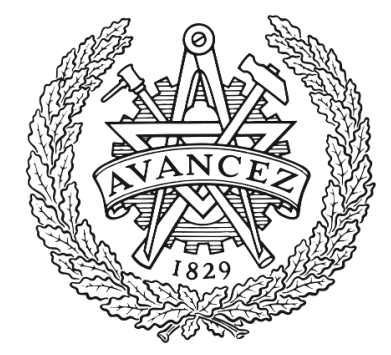

CHALMERS

UNIVERSITY OF TECHNOLOGY

\title{
Logistics service providers' energy efficiency initiatives for environmental sustainability
}

Downloaded from: https://research.chalmers.se, 2023-04-26 01:45 UTC

Citation for the original published paper (version of record):

Wehner, J., Taghavi Nejad Deilami, N., Altuntas Vural, C. et al (2021). Logistics service providers' energy efficiency initiatives for environmental sustainability. International Journal of Logistics Management, 33(5): 1-26. http://dx.doi.org/10.1108/IJLM-10-2019-0270

N.B. When citing this work, cite the original published paper. 


\title{
Logistics service providers' energy efficiency initiatives for environmental sustainability
}

\author{
Jessica Wehner, Naghmeh Taghavi Nejad Deilami and \\ Ceren Altuntas Vural \\ Chalmers University of Technology, Gothenburg, Sweden, and \\ Árni Halldórsson \\ Chalmers University of Technology, Gothenburg, Sweden and \\ Hanken School of Economics, Helsinki, Finland
}

Received 16 October 2019

Revised 9 April 2020

24 September 2020

8 March 2021

18 June 2021

15 September 2021

Accepted 16 September 2021

\begin{abstract}
Purpose - This paper discusses logistics service providers' (LSPs') energy efficiency initiatives for sustainable development, both from an evolutionary perspective and based on a framework consisting of actions, processes (i.e. at the operations interface) and services (i.e. at the customer interface).

Design/methodology/approach - Following a qualitative research design, semi-structured interviews were conducted with sustainability managers at LSPs and the data were analysed via inductive coding. Based on the results and the literature, the authors developed a maturity model for LSPs' transitions to environmental sustainability.

Findings - LSPs' sustainable development occurs via operational processes, services at the customer interface, and actions that support those processes and services. Energy efficiency efforts are characterised by process depth that helps LSPs to align with their customers' energy efficiency improvement processes. While services related to energy efficiency connect LSPs and their customers, actions in support vary depending on the logistics activities in which LSPs participate.

Research limitations/implications - Further research is needed to test and verify the maturity model and to clarify the interdependency of its three dimensions.

Practical implications - By categorising energy efficiency initiatives and proposing a maturity model for LSPs' sustainable development via energy efficiency, the authors have developed a tool for logistics actors to assess their progress towards improved sustainability.

Originality/value - The paper contributes to the literature by providing a three-pillar framework to understand the sustainability transitions of LSPs through energy efficiency. Developing a maturity model using this framework also contributes to the literature with an approach to assess sustainability advancement in the logistics industry.
\end{abstract}

Keywords Environmental sustainability, Green logistics, Logistics service providers, Maturity model,

Sustainable logistics

Paper type Research paper

\section{Introduction}

In logistics, energy is a resource that factors significantly into not only economic performance but also environmental sustainability. In the process, however, logistics operations consume vast energy resources and, in turn, produce a major share of Earth's greenhouse gas

(C) Jessica Wehner, Naghmeh Taghavi Nejad Deilami, Ceren Altuntas Vural and Árni Halldórsson. Published by Emerald Publishing Limited. This article is published under the Creative Commons Attribution (CCBY 4.0) licence. Anyone may reproduce, distribute, translate and create derivative works of this article (for both commercial and non-commercial purposes), subject to full attribution to the original publication and authors. The full terms of this licence may be seen at http://creativecommons. org/licences/by/4.0/legalcode

This work was supported by the Swedish Energy Agency-Energimyndigheten, Area of Advance Transport, Chalmers University of Technology and Logistik och Transport Stiftelsen - LTS.

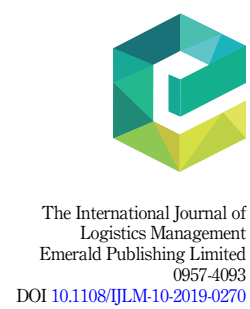


emissions (Browne, 2005). Although freight transport and business logistics can improve their environmental sustainability by pursuing energy efficiency (McKinnon, 2012; Lam and Dai, 2015; Halldórsson et al., 2019a), relative to the manufacturing sector, which has long sought energy efficiency due to rising energy costs (Schulze et al., 2016), the logistics sector responded only recently, largely to comply with EU Directives (EU, 2018) and UN sustainable development goals (United Nations, 2015) requiring transport operations to reduce their carbon emissions. Thus, whereas diverse sustainability initiatives pursued by logistics service providers (LSPs) have been proposed and examined (Colicchia et al., 2013; Evangelista, 2014; Abbasi and Nilsson, 2016; Centobelli et al., 2017a, b), pursuing energy efficiency as a means of achieving environmental sustainability, especially by decarbonising logistics operations and systems, has remained poorly understood (Kalenoja et al., 2011; Lam and Dai, 2015; Halldórsson et al., 2019a; Punte et al., 2019).

In logistics, energy efficiency, as a performance measure, refers to energy use in activities such as transport and warehousing (McKinnon, 2012). Although diverse initiatives for improving energy efficiency in logistics have been conceptualised, Martinsen and HugeBrodin (2014) have posited that such environmentally oriented initiatives are essentially either transport-related initiatives (e.g. concerning fuel, vehicle technology, modal choice, behavioural aspects and transportation management) or beyond-transport initiatives (e.g. concerning logistics system design, environmental management systems and emissions). Colicchia et al. (2013) have divided such environmental initiatives into two different broad categories - intra- and inter-organisational - while Abbasi and Nilsson (2016) have distinguished them according to their short-term versus long-term perspectives. Taking alternative approaches to the topic, Evangelista (2014) has examined which initiatives LSPs adopt in light of various drivers and barriers, and Centobelli et al. (2020) have extended that view by classifying LSPs according to the sustainability-oriented strategies that they adopt.

Although the literature identifying and categorising those various initiatives in logistics offers insight into the state of sustainability in the industry, the underlying principles of the process of developing them are less apparent. Nevertheless, investigating how LSPs pursue sustainable development with energy efficiency initiatives allows analysing a range of issues associated with environmental sustainability, and may complement the study of transport-related (Martinsen and Huge-Brodin, 2014) and/or technology-related (Centobelli et al., 2017b) initiatives in, for example, route planning and information technology (IT) systems. Moreover, emphasising the "development" part of LSPs' sustainable development by improving energy efficiency foregrounds the conceptualisation of sustainable development as a process of change, not a "fixed state of harmony" (Brundtland, 1987, p. 43). To be sure, whereas principles of mere sustainability emphasise "a certain favourable outcome", principles of sustainable development emphasise the process that generates the outcome (Robèrt et al., 2002, p. 198). However, knowledge of that process's evolutionary nature and its building blocks is currently lacking in the literature.

In logistics, the dominant approach to attaining energy efficiency as a performance measure related to cost or quality undermines the interdependence between energy efficiency and sustainability (Halldórsson and Kovács, 2010). Albeit widely based on non-renewable resources that cause pollution, the concept of energy efficiency plays a significant role in achieving environmentally sustainable development in logistics as well (Golichich et al., 2010; Taptich et al., 2016). As such, energy efficiency is not only a performance measure but also an area for improvement. However, how such improvement enables the evolution towards sustainable development in logistics is another aspect neglected in the literature.

This article investigates the sustainable development of LSPs [1] by exploring their energy efficiency initiatives from an evolutionary perspective. In doing so, it contributes to the literature in two ways. First, as a result of analysing LSPs' sustainable development through energy efficiency, it captures formal and informal initiatives related to both internal operations and the external market. Such focus on energy efficiency provides in-depth insight 
into a particular range of actions, processes and services, organised in a three-pillar framework, that LSPs can engage in to advance their sustainability. Second, by elucidating the degree of advancement with those actions, processes and services, the findings offer an evolutionary perspective on the sustainable development of LSPs. Based on those findings, the article proposes a maturity model for LSPs' sustainable development that can assist both researchers and practitioners in understanding the varying degrees of maturing in their energy efficiency initiatives.

The remainder of the paper is structured as follows. Section 2 explains the three building blocks of LSPs' energy efficiency initiatives for sustainable development: actions, processes and services. Next, Section 3 describes the method, after which Section 4 presents the results in relation to the building blocks. Section 5 discusses the attributes of the building blocks in relation to the literature and proposes a maturity model for LSPs' sustainable development. Last, Section 6 concludes with implications for research and practice.

\section{Literature and framework}

Departing from current classifications of environmental initiatives taken by LSPs (Martinsen and Huge-Brodin, 2014; Lam and Dai, 2015; Centobelli et al., 2017b; Evangelista et al., 2018), we developed a theoretical framework for enhancing sustainable development through energy efficiency initiatives with three building blocks: actions, processes and services. Together, the building blocks capture the variety of formal and informal efforts, concerned with either internal operations or external customer offerings, undertaken by LSPs for environmental sustainability. First, actions are general efforts towards achieving energy-efficient outcomes that also form the basis for the other two building blocks, that is, processes and services. Second, processes are structured sequences of planned actions, often embedded in management systems and that affect internal operational settings. Third, services are externally oriented efforts towards improving energy efficiency via market offerings designed for and delivered to customers.

\subsection{Actions}

Considering the large share of their operations devoted to transportation, LSPs perform certain actions to alter the energy efficiency of their vehicles, including changing their vehicle fleet (Colicchia et al., 2013), enhancing capacity utilisation (Léonardi and Baumgartner, 2004), implementing new technologies (Vujanovic et al., 2010), using alternative fuels (Colicchia et al., 2013) and designing new vehicles. Although LSPs cannot directly influence the demand for transport, they can act to minimise traffic within given boundaries (Roth and Kåberger, 2002) by using IT to plan effective routes (Baumgartner et al., 2008) and/or altering the mode of transport (Evangelista, 2014).

To add to those transport-related actions, other authors have pinpointed actions for energy efficiency in warehouses and buildings managed by LSPs (Perotti et al., 2012) and regarding waste management and recycling at LSPs (Piecyk and Björklund, 2015). Other inter-organisational actions include initiatives to collaborate with external partners and to reconfigure supply chains for better environmental planning (Evangelista et al., 2018), all of which can support the development of formal processes for improving internal operations and customer service offerings. As such, the actions can be internal to organisations or external if performed with other actors (e.g. suppliers or customers). In either case, they support the development of LSPs into more environmentally sustainable organisations.

\subsection{Processes}

The second building block concerns LSPs' internal processes that promote energy efficiency. Fundamentally changing the design of new processes and retrofitting existing ones are both
LSPs' energy efficiency 
means to reducing the organisations' negative impact on the environment (Diwekar, 2005) by using fewer materials, consuming less water and energy, and reducing environmental pollution (Prajogo et al., 2014). As an approach to sustainable development, energy efficiency is less widely established in the logistics sector than in the manufacturing sector, the latter of which has long succeeded in using resources efficiently via formalised management systems, including energy efficiency practices (Halldórsson et al., 2018), and process models for measuring organisation-wide energy efficiency (Schulze et al., 2016). Research has suggested that LSPs, by contrast, may not implement formal processes because they are considered to be time-consuming in an industry that needs rapid decision-making to satisfy customers' immediate needs and demands (Franklin, 2008). More recent research has indicated, however, that LSPs do extend sustainability into their practices while fulfilling environmental regulations, policy requirements and to meet customers' demands for energy efficiency (Evangelista, 2014). Of those practices, ones that can be associated with the formal, internal nature of processes have been grouped in the categories of formal programmes (Lieb and Lieb, 2010a), administrative and analytical tasks (Lieb and Lieb, 2010b), so-called "greening 3PLs activities" (Isaksson and Huge-Brodin, 2013), intra-organisational practices (Colicchia et al., 2013), "green solutions" that impact LSPs as companies (Evangelista, 2014) and singlefirm initiatives (Centobelli et al., 2017b). The diversity of those labels indicates no focus on the formalisation or status of the practices, largely because previous efforts in classification have built upon other approaches instead. For all of those reasons, processes in our framework are LSPs' formal internal and planned, systematic efforts towards achieving sustainable development by promoting energy efficiency.

\subsection{Services}

Given the literature's predominant focus on internal aspects of LSPs' green offerings (Isaksson and Huge-Brodin, 2013), the conceptual boundaries of improvement in any direction are often restricted within the organisational boundaries of LSPs. Therefore, complementary to the internal processes is a customer-oriented perspective, according to which LSPs seek to decrease the environmental impact by altering their service offerings to customers. In that field, LSPs' environmental initiatives have gained particular attention; they range from broadly defined external initiatives (Pieters et al., 2012) and efforts in customer orientation (Isaksson and Huge-Brodin, 2013) to more inter-organisational (Colicchia et al., 2013) and supply chain initiatives (Evangelista, 2014) that can be associated with logistics services (Evangelista et al., 2018). From that standpoint, the sustainable development of LSPs is essential to achieving sustainable development throughout the supply chain given LSPs' critical role in its various stages (Brockhaus et al., 2013; Laari et al., 2018; Reinerth et al., 2018). Just as considerations of climate change urge manufacturing companies and actors in their supply chains to adopt principles of environmental sustainability (Sarkis, 2003; Seuring and Müller, 2008), they also demand sustainable service offerings from LSPs (Lieb and Lieb, 2010a; Wolf and Seuring, 2010; Multaharju et al., 2017).

Compared with knowledge about internal processes, knowledge about the external element of customers has remained underdeveloped. Even so, cost and utility clearly dominate customers' criteria for selecting LSPs, whereas environmental considerations remain tertiary (Martinsen and Björklund, 2012; Bask and Rajahonka, 2017). Most of the studies in the literature on the topic take the perspective of shippers, explores whether customers perceive environmental initiatives as important when selecting LSPs (Wolf and Seuring, 2010) or investigates the extent to which customers value the initiatives when purchasing logistics services (Martinsen and Björklund, 2012). Evidence suggests that costbased evaluation, especially when buying transportation services, remains prevalent due to 
the industry's highly competitive structure (Oberhofer and Dieplinger, 2014). By contrast, explicit stipulations to use sustainable modes of transport in official documents or contracts seem to be only an emerging concept (Bask and Rajahonka, 2017).

We have adopted the term services to denote the external, customer-facing perspective of initiatives toward environmental sustainability. This includes services such as carbon dashboarding, carbon offsetting, life cycle assessment for transportation and others that support the environmental sustainability of LSPs' customers and their networks (Halldórsson and Altuntas Vural, 2019). Although research on services as such has grown significantly during the past decade, in logistics, especially in research on transportation, the concept of services has remained in its infancy (Busse and Wallenburg, 2011). Beyond that, despite increased attention paid to environmental logistics initiatives (Liimatainen et al., 2012, 2014; Colicchia et al., 2013; Evangelista, 2014; Centobelli et al., 2017b), a specific focus on the green or environmental services that LSPs provide has yet to be developed (Gammelgard and Prockl, 2012).

\subsection{Synthesis}

Our study's conceptual approach consists of three building blocks: actions, processes and services. Whereas the literature offers detailed insight into initiatives related to actions and processes, we add new depth to such knowledge by considering sustainability associated with those actions and processes in light of energy efficiency. Moreover, including services in the approach facilitates an inter-organisational, customer-oriented perspective on LSPs' sustainable development. Such an approach complements research focused on customers' perceptions (e.g. Wolf and Seuring, 2010; Martinsen and Björklund, 2012) and the positioning of environmental logistics services in business relationships between LSPs and their customers (Martinsen and Huge-Brodin, 2014), chiefly by differentiating services from actions and processes and by analysing their role not in sustainability per se but in the sustainable development of LSPs.

Our literature review revealed that sustainability-oriented initiatives vary not only in their form and formalisation, as the three categories of actions, processes and services indicate, but also in their level of success. Because the patterns of initiatives (Isaksson and Huge-Brodin, 2013) as well as their intensity (Centobelli et al., 2017a) vary amongst LSPs, one way of introducing variety in their levels of achievement is via staged approaches such as maturity models (Becker et al., 2009). Predominantly used in manufacturing and developed in fields such as product development (Hynds et al., 2014), innovation (Chiesa et al., 1996) and supply chain integration (Geary et al., 2002), maturity models have only relatively gained traction in the domains of sustainability (Wendler, 2012) and energy (Antunes et al., 2014). The models, as multi-stage tools for assessment and systematic improvement (Reefke et al., 2014; Machado et al., 2017), are designed to evaluate an organisation's capability and/or competency in a selected domain according to a comprehensive set of criteria (de Bruin et al., 2005). As such, they outline an evolutionary path of systematic improvements, ranging from initial, basic states of compliance in organisations to integrated systems for sustainability (Reefke et al., 2014; Machado et al., 2017). Moreover, they prescribe gradual development built upon the principle of continuous improvement in total quality management, beginning with planning and followed by assessing organisations throughout the stages of implementation, monitoring and improvement (Antunes et al., 2014; Reefke et al., 2014).

\section{Method}

\subsection{Sampling and data collection}

Because improving energy efficiency is arguably a nascent means of achieving sustainable development amongst LSPs (Edmondson and McManus, 2007), we conducted semi- 
structured interviews with multiple LSPs to explore their knowledge of and experiences with actions, processes and services related to energy efficiency initiatives (Flick, 2014). Energy efficiency is an analytical construct (Cunliffe, 2011) insofar as it focuses on what should be improved. However, for our study's purpose, energy efficiency initiatives were positioned as empirically observable entities. The focal point of departure is energy efficiency for environmental improvement. Energy efficiency was chosen, as it concerns improvements that derive from technical, behavioural or economic changes (Swedish law, 2014), and it relates simultaneously to both economic and environmental performance. It is a construct where "planet" meets "profit" (Halldórsson et al., 2019b). For example, the type and amount of energy being used in turn influence the way by which LSPs transform into sustainable organisations, and they adapt their logistics actions, processes and services to that. This enables operationalizing and classifying the efforts for improvement in comparison to more general terminology such as green initiatives or sustainability initiatives. We used energy efficiency with this as a perspective to capture what interviewees said (i.e. an in vivo code) and expressed interest in, especially for improvements based on energy mapping.

To recruit interviewees, we employed purposive sampling (Bryman and Bell, 2011), which began by identifying LSPs in light of the study's purpose. Swedish law (2014, p. 266) that requires large companies which have more than 250 employees and an annual turnover exceeding EUR 50 million to develop a systematic approach for continuously improving energy efficiency and to do regular energy mapping was used as a basis to select the sample. Formerly, this definition covered only manufacturing companies; as LSPs got larger, they started to fit into the definition and were obliged to do systematic energy mapping. Therefore, initially, the sample comprised large LSPs required to conduct energy mapping per Swedish law. However, to reach theoretical saturation (Corbin and Strauss, 2008), the sample was expanded to include several other large LSPs that are candidates for future regulations due to their size and activities. As a result, sampling yielded nine LSPs.

In a second step, interviewees were selected from those nine LSPs in consideration of their in-depth experience with environmental sustainability and their responsibilities for improving energy efficiency. An initial interview guide was developed based on Schulze et al.'s (2016) integrative energy management framework, chosen for its comprehensive focus on multiple aspects of energy management in manufacturing organisations. However, the first phase of data collection revealed differences between manufacturing and logistics sectors and how regulations designed for the former do not cover all aspects of the latter (e.g. plant machinery and layout, and cooling and ventilation of facilities). Beyond that, the interviewees struggled to relate to all of the dimensions of energy management in the framework. Therefore, the interview guide was modified based on insights from the first phase of data collection and in light of the three conceptual building blocks. Some terminology was also adjusted in order to make the questions more comprehensible. Ultimately, five interviews were performed following the initial interview guide and four following the revised one. During interviews, interviewees provided company-specific documents (e.g. presentations and reports) as secondary data to furnish new insights and validate the findings from the analysis of data from interviews. Table 1 provides an overview of the sample.

\subsection{Data analysis}

All interviews were recorded with the interviewees' permission and transcribed verbatim, after which data were analysed iteratively in relation to the study's analytical framework (Miles et al., 2020; Corbin and Strauss, 2008). Analysis followed three steps. First, open codes were formed from raw data to understand what the interviewees meant (Fawcett et al., 2014). Second, axial coding was performed to understand the codes in new and different ways and to 


\begin{tabular}{|c|c|c|c|c|}
\hline No. & Type of LSP & $\begin{array}{l}\text { Interview date and } \\
\text { duration }\end{array}$ & Interviewee position & $\begin{array}{l}\text { LSPS energy } \\
\text { efficiency }\end{array}$ \\
\hline LSP1 & $\begin{array}{l}\text { Freight forwarder by road and } \\
\text { rail }\end{array}$ & November 2017, $100 \mathrm{~min}$ & Process and environment manager & \\
\hline LSP2 & $\begin{array}{l}\text { Freight forwarder for express } \\
\text { deliveries by road and air }\end{array}$ & December 2017, 55 min & Sustainability manager & \\
\hline LSP3 & Freight forwarder & December 2017, $40 \mathrm{~min}$ & Environmental manager & \\
\hline LSP4 & Third-party logistics provider & December 2017, 60 min & $\begin{array}{l}\text { Environment, energy, and quality } \\
\text { manager }\end{array}$ & \\
\hline LSP5 & $\begin{array}{l}\text { Waste logistics provider by } \\
\text { road }\end{array}$ & November 2017, $65 \mathrm{~min}$ & $\begin{array}{l}\text { Logistics development manager and } \\
\text { environmental manager }\end{array}$ & \\
\hline LSP6 & Freight forwarder by sea & January $2018,95 \mathrm{~min}$ & Performance manager & \\
\hline LSP7 & Fourth party logistics provider & March 2018, 75 min & Site manager and general manager & \\
\hline LSP8 & $\begin{array}{l}\text { Freight forwarder by road and } \\
\text { rail }\end{array}$ & March 2018, 60 min & Distribution manager & $\begin{array}{r}\text { Table 1. } \\
\text { Descriptive }\end{array}$ \\
\hline LSP9 & Third-party logistics provider & $\begin{array}{l}\text { April 2018, } 50 \mathrm{~min} \text { and } \\
\text { May 2018, } 55 \mathrm{~min}\end{array}$ & $\begin{array}{l}\text { Transport manager and } \\
\text { Sustainability manager }\end{array}$ & $\begin{array}{r}\text { information regarding } \\
\text { the sample }\end{array}$ \\
\hline
\end{tabular}

pinpoint relationships amongst them (Ellram and Tate, 2015). Third, refined axial codes were constantly compared with the three building blocks of the analytical framework (i.e. actions, processes and services). Two researchers from the research group performed coding in different rounds, and in a final round of coding, axial codes were refined, and the matches between codes and analytical categories were discussed. Following analysis, a third researcher reviewed the data set in a final round of refinement. Throughout coding, the literature was continually examined, and field notes and company documents were used to gain insight into the companies' energy efficiency initiatives. So-called "proof quotes" and "power quotes" (Pratt, 2008) from the data set were selected to present both the results and the chain of evidence. Table 2 illustrates the coding process with some exemplary codes and quotations.

\subsection{Research quality}

The study's quality and trustworthiness were evaluated for their credibility, transferability, dependability, and confirmability, as commonly pursued in qualitative research (Miles et al., 2020) and logistics studies (Halldórsson and Aastrup, 2003). First, the iterations of coding and data analysis provided a chain of evidence, while the continual discussion of findings in the research group helped to assure credibility, meaning to understand the respondents' constructed realities within the selected context through multiple iterations. Furthermore, the results were discussed with selected interviewees for validation. Second, for transferability, or external validity - in qualitative research, the extent to which claims made in one research context could be transferred to other contexts - we validated the study's findings by discussing them in relation to the literature to ensure analytical generalisability. On top of that, conducting multiple interviewees and providing data descriptions with power quotes (Pratt, 2008) afforded richness of detail, while developing an analytical framework and a maturity model confirmed the transferability of findings to other contexts. As a result, general categories and multiple levels of achievement were identified that LSPs can use in practice and that scholars can use to test the model. Third, dependability - that is, the stability of data over time, meaning whether the study and its results can be reconstructed - was ensured by recording all interviews and examining all documents, following the same protocol in all interviews, documenting all methodological processes and decisions, and providing a detailed description of the research process. Last, confirmability, defined as the 
IJLM

\begin{tabular}{|c|c|c|c|}
\hline Proof quotes & Open codes & Refined axial codes & $\begin{array}{l}\text { Theoretical } \\
\text { categories }\end{array}$ \\
\hline $\begin{array}{l}\text { "So, we started .... to do our own vehicles on } \\
\text { trolley electrics" } \\
\text { "Testing a company to construct an electric } \\
\text { bike for deliveries" } \\
\text { "Engaged with .... electrical self-driving } \\
\text { trucks" }\end{array}$ & $\begin{array}{l}\text { Test different } \\
\text { solutions } \\
\text { Sustainable } \\
\text { vehicle design } \\
\text { Innovative } \\
\text { initiatives } \\
\text { Electric vehicles } \\
\text { Electrification }\end{array}$ & Vehicles & Action \\
\hline $\begin{array}{l}\text { "We work with Ships Energy Efficiency } \\
\text { Management Plan (SEEMP) ..... for every } \\
\text { vessel" }\end{array}$ & $\begin{array}{l}\text { Planning for } \\
\text { operations }\end{array}$ & $\begin{array}{l}\text { Operations } \\
\text { management } \\
\text { process }\end{array}$ & Process \\
\hline $\begin{array}{l}\text { "The better [the] fill rate we have in our trucks } \\
\ldots \text { the cheaper our production is, and the } \\
\text { fewer [the] trucks we need to use here" }\end{array}$ & $\begin{array}{l}\text { KPIs } \\
\text { Monitoring KPIs } \\
\text { Optimised } \\
\text { transport } \\
\text { Capacity } \\
\text { utilisation } \\
\text { Supply process }\end{array}$ & & \\
\hline $\begin{array}{l}\text { "Also measure how much energy we use per } \\
\text { handled piece inside a terminal" }\end{array}$ & $\begin{array}{l}\text { Risk management } \\
\text { process }\end{array}$ & & \\
\hline $\begin{array}{l}\text { "If [a] customer demands sustainability, we } \\
\text { will be delivering it" } \\
\text { "...\% of our services to customers should be } \\
\text { green according to our targets" }\end{array}$ & $\begin{array}{l}\text { Customer demand } \\
\text { Supply chain } \\
\text { sustainability } \\
\text { Green service } \\
\text { Service KPIs }\end{array}$ & $\begin{array}{l}\text { Demand for } \\
\text { sustainable services }\end{array}$ & Service \\
\hline
\end{tabular}

Table 2.

Example of data analysis degree to which results are free of bias, was achieved by using multiple sources of evidence (e.g. informants and documents) and discussing the results with managers and other researchers.

In the next section, to acknowledge the variety of approaches and levels of achievement, the results associated with the three building blocks are discussed from an evolutionary perspective with reference to a maturity model. Such an approach extends classifications of LSPs' sustainability-oriented initiatives that focus on topics (Evangelista et al., 2018) and/or types of functional services (Centobelli et al., 2017a) by addressing the various forms of initiatives, their degree of formalisation and the extent to which LSPs apply or adopt them.

\section{Results: LSPs' initiatives for improving energy efficiency}

Following the summary in Table 3 , this section presents the empirical findings regarding the three building blocks (i.e. actions, processes and services) of LSPs' energy efficiency initiatives.

\subsection{Actions}

Derived from the evidence, the following actions are categorised into five groups, ranging from actions related to physical resources to managerial actions.

4.1.1 Building design. LSPs have improved energy efficiency in their buildings (i.e. office buildings and terminals) and facilities by converting to LED lights, geothermal heating and solar panels. Such investments are typically enabled by longer rental contracts: "If we sign a rental agreement for maybe 3 or 5 years, then the landlord, together with us, has an easier way 


\begin{tabular}{|c|c|c|c|c|}
\hline Category & Dimension & $\begin{array}{l}\text { Mentioned } \\
\text { by }\end{array}$ & Related keywords & $\begin{array}{l}\text { LSPs' energy } \\
\text { efficiency }\end{array}$ \\
\hline \multirow[t]{5}{*}{ Actions } & Building design & $2,3,4,8,9$ & LED lighting, rental contracts, solar & \\
\hline & Vehicle-related actions & $\begin{array}{l}1,2,3,5,6,8 \\
9\end{array}$ & $\begin{array}{l}\text { Electric vehicles, autonomous vehicles, } \\
\text { fuels economy }\end{array}$ & \\
\hline & $\begin{array}{l}\text { Information and communication } \\
\text { technology-related actions }\end{array}$ & $5,7,8$ & Real-time planning, data collection & \\
\hline & $\begin{array}{l}\text { Managerial actions: collaboration } \\
\text { and encouragement }\end{array}$ & $\begin{array}{l}1,2,3,4,5,6 \\
7\end{array}$ & $\begin{array}{l}\text { Collaboration, encouragement, } \\
\text { incentives }\end{array}$ & \\
\hline & Monitoring and reporting & $\begin{array}{l}1,4,5,6,7,8, \\
9\end{array}$ & Supplier control, audits & \\
\hline \multirow[t]{7}{*}{ Processes } & Energy mapping & $1,2,3,4,5,9$ & $\begin{array}{l}\text { Energy data, extension to transport } \\
\text { activity and vehicles }\end{array}$ & \\
\hline & $\begin{array}{l}\text { Measuring environmental } \\
\text { performance }\end{array}$ & All & $\begin{array}{l}\text { KPIs, centralized vs. decentralized } \\
\text { measurement, carbon invoicing }\end{array}$ & \\
\hline & $\begin{array}{l}\text { Environmental management } \\
\text { systems }\end{array}$ & All & $\begin{array}{l}\text { ISO 50001, management of } \\
\text { sustainability, continuous improvement }\end{array}$ & \\
\hline & Operations management & 1,9 & $\begin{array}{l}\text { Capacity planning, waste management, } \\
\text { supply processes }\end{array}$ & \\
\hline & Environmental training & $1,2,3,4,6,9$ & Driver training, raising awareness & \\
\hline & Documentation and communication & $2,3,4,5,7$ & Environmental goals, top management & \\
\hline & Investments & $1,3,4,8,9$ & $\begin{array}{l}\text { Sustainable projects, internal } \\
\text { competition }\end{array}$ & \\
\hline \multirow[t]{2}{*}{ Services } & $\begin{array}{l}\text { Sustainable transport solutions and } \\
\text { deliveries }\end{array}$ & $1,2,4,7,8,9$ & Intermodal transport, full truckloads, & Table 3. \\
\hline & Other sustainable services & $1,6,7,8,9$ & Emission calculation, carbon offset & $\begin{array}{l}\text { empirical } \\
\text { results }\end{array}$ \\
\hline
\end{tabular}

to actually invest in the building and get those energy savings" (LSP4). Other efforts have included actions such as shutting off lights in terminals and regulating the behaviour of personnel. As one LSP stated, "There are a lot of examples that we've identified when someone gets to work an hour earlier than everyone else because he or she thinks that it's good to be there and prepare, which requires lighting up the entire warehouse. But we will not have any operations there for maybe an hour, so it'll cost a lot of money and energy over the course of a year" (LSP4).

4.1.2 Vehicle-related actions. The LSPs explained that their initiatives for new and innovative vehicle designs have been challenged by their scarcity in the market and the limited ability of electric trucks to carry the same weight as their fossil-fuelled counterparts. Moreover, as one LSP explained, the infrastructure for electric vehicles needs further development: "We would love to buy another alternative, but today there are not any. ... Some companies have started to provide electric trucks. But it's not just the truck; it's much more complicated. We need infrastructure; we need the availability of sustainable electricity". Challenges in the supply of biofuels were also highlighted: "If you look at transport emissions, what alternatives are there to the combustion engine and diesel? ... Every single biofuel produced in Sweden is used, I would say" (LSP9). In another approach, vehicle conversion, LSPs update their fleets with more energy-efficient vehicles or electric vehicles, which can involve radical changes in the use of vehicles, including using bicycles, particularly for delivering mail, testing autonomous vehicles and connecting fleets.

4.1.3 Information and communication technology-related actions. Information and communications technology has been used by several LSPs to enhance their energy efficiency, for example, through route planning, real-time planning to reduce delays, and monitoring drivers' behaviour (i.e. LSP5, 7 and 8). 
4.1.4 Managerial actions: collaboration and encouragement. Managerial action is formulated as a decentralised approach for taking initiatives, instead of waiting for a topdown approach to their implementation. Although one LSP emphasised collaboration with suppliers and other actors to foster sustainable development, most managerial actions mentioned have primarily been associated with internal encouragement. For example, one LSP described adopting a mindset of continuous improvement: "Everything that we do is aimed at using less energy when we're buying a new vehicle or planning" (LSP5). Such a mindset requires encouragement and incentives, however, "In some cases, it's active leadership; if you see something, then you need to act on it to actually encourage good behaviour. That's the best way to do it, and, then, of course, there's the traditional way of having switch-off campaigns and stickers about turning off lights, closing doors, and adhering to the site's rules to ensure that those basics are in place" (LSP4). Some LSPs reported using environmental funds to encourage ideas for new projects, for example, an internal competition for a fund that employees can apply for to promote energy efficiency. Those and other internal incentives are diversified to encourage the development of new actions for improved energy efficiency.

4.1.5 Monitoring and reporting. Continuously monitoring energy-related data was identified as a key activity for improved energy efficiency, including the monitoring of LSPs' suppliers: "Our operation is one leg, then it's in the supplier's control, because a lot of emissions are made there. So, we need to be really firm with demands from for our subcontractors, and the third leg is actually customer-related dialogue" (LSP9). Several LSPs highlighted regularly reporting energy consumption, especially emissions.

\subsection{Processes}

The LSPs have additionally established various internal processes that directly or indirectly aim to improve their energy efficiency.

4.2.1 Energy mapping. Most of the LSPs reported regularly conducting energy mapping, which traditionally involves mapping the energy consumption of office buildings, facilities, and terminals, not vehicles and modes of transportation. However, with the introduction of Swedish law (2014, p. 266) stipulating energy mapping at large companies beyond processing and manufacturing activities, the vehicle fleets and transport activities of LSPs also need to be accounted for. Whereas the LSPs expressed wanting to work with the same external consultants for mapping the energy of their vehicles that they have for mapping their buildings and terminals, they have realised that evaluations of vehicles and transport activities are unavailable. One LSP stated, "The external auditor knew a lot about the facility and buildings, but he did not know much about transport or vehicles" (LSP5). Energy mapping is also regarded as a more systematic approach than previously employed practices: "We have lights on at night when no one is working. You can understand that without doing an audit, and maybe we found those things [in the past]. However, I think that now we have a much more systematic approach, and we'll find many more things, and maybe we'll see the connection between them" (LSP5). One LSP characterised the use of ISO 50001 as one such systematic approach, one that extends the scope of the energy mapping of vehicles to include subcontractors, which generate the lion's share of emissions. Another LSP reported that whereas energy data on objects that they own are monitored continuously, energy data from suppliers are collected only yearly. Energy mapping is also used to assess risks in costbenefit assessments regarding the possible negative impacts of individual activities.

4.2.2 Measuring environmental performance. The process of measuring environmental performance involves following up on the results of energy mapping by comparing them with key performance indicators (KPIs) or other internal benchmarks used for continuous improvement. Having the data, however, does not automatically lead to their use: "There's the 
reporting of consumption figures, and that also includes transport. ... But we're not only looking at actual numbers, because the business goes up and down, so we need to create KPIs and have follow-up" (LSP4). One LSP explained how information is further considered in service exchanges with customers by adding emissions to their invoices, such that they receive reports on their carbon emissions along with the price of the service. Organising measurement ranges from having a main office being responsible for comparing the different sites to a more decentralised approach that requires the follow-up on targets as a responsibility of the individual sites.

4.2.3 Environmental management systems. All LSPs reported having an environmental management system in place. One LSP observed that ISO 50001 was induced by top management although customers had mostly requested ISO 9001 and 14,001 only. Furthermore, whereas sustainability goals have been established primarily by top management, individual initiatives and action plans towards accomplishing those goals have originated in different subunits: "Initiatives come from either our sustainability officer or ... directly or indirectly from the head office here, but they can also be locally developed at our branches and by individual employees. We're ... part of a big group ..., so of course there's a sustainability programme and an umbrella here, as well as ambition. However, we've set global targets with the help of our group" (LSP9). To be effectively realised, goals need to be handled by the site managers who are close to the operation: "So, the site manager needs to own that agenda. You need to do that so that things happen, so it needs to be done locally. I can set a fancy target, and I can propose actions, but they need to be pursued by the business and where the action happens at the different sites" (LSP5). Along with formal, dedicated systems such as ISO 50001, LSPs reported seeking energy efficiency as part of their efforts towards continuous improvement: "A culture of continuous improvement is built into the company, so anyone who wants to contribute can suggest ideas, and it's usually picked up locally, and if there are good ideas, then they spread throughout the organisation" (LSP2). One LSP, drawing a broad scope on who shoulders responsibility for environmental sustainability, explained that "every employee is responsible for the environment" (LSP1).

4.2.4 Operations management. Energy efficiency has also been pursued via internal operations management processes such as capacity planning and supply. Having a process for capacity planning in place for freight transport on rail and road is important; according to one LSP, "We do not really know how many pallets or how many parcels we'll pick up every day; that's part of the daily business for management. So, they're very good at getting the right capacity, the right numbers of terminal blue collars, and so on. So, we have a base capacity, and we have the human resources, which are changing every day" (LSP1).

Supply, another operations management process, refers to the price-bargaining power of LSPs over fuel with second-tier suppliers: "Our subcontractors can buy their fuel, and we pay, and then we deduct that amount from the money they'll get from us. That way, we have bargaining power over second-tier suppliers" (LSP1).

4.2.5 Environmental training. Internal training processes to facilitate eco-consciousness and environmentally friendly behaviours have been implemented in several LSPs. The degree of those measures' implementations has varied, and training has taken various forms, including driver training for energy-efficient driving skills, e-learning programmes provided three times a year and online education packages for employees. An LSP that lacks dedicated training for energy efficiency stated, "We do not really have an energy training as such, but we train people to be efficient in their daily lives, in their daily work" (LSP2). Another admitted that the structure for such training is underdeveloped: "We have some training ..., but last year we performed poorly on that" (LSP4).

4.2.6 Documentation and communication. Goals for energy efficiency decided by top management are communicated internally to different subunits as "any other goal in the company", that is, "from top management down to different departments" (LSP5). With such 
communication, employees have to understand what they do and its impact: "It should be something that they understand daily; if I do the right thing according to our priorities of being efficient in production, then it will contribute to energy and environmental efficiency" (LSP2). In addition, formalised internal and external communication processes are in place by which different versions of sustainability reports that inform goals and actions taken for sustainability are published by many LSPs.

4.2.7 Investments. Investments in projects and pilot projects were mentioned as a way of encouraging innovation and development. Not only do formalised processes promote the proposal, discussion and approval of investment ideas by central management teams, but systematic application processes exist for such investments. It was acknowledged that the return is not always determined upfront or visible in the short term: "We're spending money on projects and pilots and so on that are not having any influence on direct financial payback, but we're setting aside funds for that" (LSP9).

\subsection{Services}

Third and last, LSPs also reported offering various services to enhance sustainable development at the customer end of the supply chain.

4.3.1 Sustainable transport solutions and deliveries. Although energy efficiency can be associated with transport-related solutions (e.g. intermodality and full truckloads), integrating sustainability into logistics services was regarded as a challenge: "Our main task, according to our customers, is to reduce costs, not environmental impact. Moreover, that does not benefit energy efficiency" (LSP6). Other LSPs mentioned integrating sustainability in their business via customised approaches, namely by finding the best solution for each specific customer either by offering them intermodal transportation or a solution that reduces emissions: "We offer intermodal transport to our customers and choose the most sustainable solution for them - that includes transport by train and short sea shipping" (LSP7). Other customised logistics solutions offered to large customers enable LSPs to bypass the terminals and deliver full truckloads directly to their destinations (LSP8). One LSP elaborated on the risk related to the increased intermodality of transport: "A major concern is risk, because often if you combine different types of transportation - for example, you perform one leg with an airplane, another with a truck, and then some with rail, ... then you can usually reduce emissions quite a bit. However, that poses the increased risk of delay, so the customer needs to be fully aware and on board with the increased risk" (LSP9).

4.3.2 Other sustainable services. In addition to transportation offerings, several LSPs reported providing other sustainable services to their customers, including climate compensation or carbon offsetting as well as emission reports and calculations to their customers: "Because the customers want emission reports from us, we, as a company, need to measure ourselves and our network" (LSP1). Another LSP described a more extensive service involving the optimisation of the transportation system and the use of IT systems (LSP7). Additional services include the electronic handling of invoices to reduce paper usage, waste and/or returns from customers.

\section{Discussion}

We investigated the sustainable development of LSPs by exploring their energy efficiency initiatives from an evolutionary perspective. Overall, using energy efficiency as an analytical construct and the focal unit of departure for improvement efforts allowed two significant contributions. First, derived from the findings, a framework of energy efficiency initiatives has been proposed, composed of actions, processes and services through which LSPs can direct their efforts related to energy efficiency. The framework responds to calls emphasising the role of energy efficiency in developing environmentally sustainable logistics (Tacken 
et al., 2014; Abbasi and Nilsson, 2016; Centobelli et al., 2020). Second, responding to the variety of LSPs' practices and achievements in the three categories, the analysis of the findings took an evolutionary perspective (Banoun et al., 2016). Although such a perspective has been evinced in the literature (e.g. Isaksson and Huge-Brodin, 2013; Evangelista, 2014), we extended it to envision a systematic pathway for the sustainable development of LSPs, captured in a maturity model. The model helps to structure the complexity (Liljestrand $e$ al., 2015) of LSPs' avenues for improving their sustainability and aligns the various sustainability initiatives previously classified under service functions (Centobelli et al., 2017a) or organisational borders (Colicchia et al., 2013) with the three building blocks of the framework that represent a certain level of achievement.

\subsection{Process depth, service bridge and effort variety}

Overall, the findings confirm that the sustainable development of supply chains focuses on energy efficiency (Centobelli et al., 2020) and that logistics operations respond well to the conventional categorisation of intra-versus inter-organisational initiatives (Evangelista et al., 2018; Colicchia et al., 2013) and transportation-oriented initiatives versus other initiatives (Lieb and Lieb, 2010). The analysis of the three building blocks - actions, processes and services -afforded new insight into how LSPs advance sustainable development via energy efficiency: process depth, service bridge and effort variety.

5.1.1 First, process depth. Processes for energy efficiency initiatives involved having LSPs set routines, assign process owners and utilise certain resources to produce energy efficiency outputs. That finding aligns with the results of Abareshi and Molla (2013), which show that by adopting effective processes, LSPs can enhance their capabilities with integrating green knowledge into their logistic operations. Compared with past findings, our results showcase distinct indicators of depth in processes, in which a range of initiatives are dedicated to energy efficiency, including energy mapping, energy performance measurement and energy systems. Therein, LSPs seem to have followed the lead of the manufacturing sector where, for example, lean models aid companies in formalising a process for energy efficiency (Abreu et al., 2017). The findings also suggest, however, that regulations and the quest for a formal process (e.g. by mapping processes for energy consumption) have driven recent interest in energy efficiency amongst LSPs.

5.1.2 Second, service bridge. Whilst the findings suggest that energy efficiency resonates well with external, supply chain-oriented initiatives, the concept of services can also take a customer-oriented perspective (Evangelista et al., 2018) or denote collaboration with customers (Colicchia et al., 2013) in three respects. First, transport services can be offered as energy-efficient options. Second, LSPs can offer non-logistics services dedicated to improving customers' environmental sustainability via carbon measurement and carbon-offsetting services, which are based on the LSPs' ability to work with processes such as energy mapping. Last, the ability of LSPs to manage customers' demands by combining economic and environmental aspects in solutions will impose further demands for transport-related and/or other services dedicated to environmental sustainability. Services offering such connections bridge the providers' own actions and processes with customers' supply chain initiatives (Evangelista et al., 2018) and can be regarded as resulting from innovative energy efficiency processes by LSPs that create opportunities previously unknown to both parties (Pieters et al., 2012). However, the bridging role of services does somewhat challenge research showing that customers do not push the demand for environmentally sustainable logistics services (Martinsen and Björklund, 2012; Nilsson et al., 2017), but that they are mostly driven by LSPs' internal motives. LSPs nevertheless think that pushing for environmental sustainability is necessary, especially if the market is not demanding it in particular, as a way to encourage the use of services able to enhance sustainability in logistics provision. 
5.1.3 Third, effort range. The results for all three building blocks - actions, processes and services - indicated considerable diversity in the definition and operationalisation of energy efficiency by the LSPs. Such trends can be explained by differences in the logistics activities provided (Isaksson and Huge-Brodin, 2013), including ownership of warehousing or distribution centres and transport fleets. Moreover, because LSPs provide cold chain services, they focus on the energy consumption of the special equipment that they provide. Other LSPs provide reverse logistics services and thus seek to recover energy both from reverse flows and from the material being transported. Although such fragmentation makes it difficult for LSPs to adopt processes similar to those in manufacturing, a better understanding of the variety of initiatives is needed.

\subsection{A maturity model for the sustainable development of LSPS}

The framework used for data collection allowed to reveal a staged structure for the energy efficiency initiatives adopted by LSPs. The data and findings indicate that different LSPs are at different stages of achieving sustainability-oriented actions, processes and services, ranging from non-existent to both internally and externally integrated. The pattern emerged from the data was compared with earlier maturity models in the literature which led to the proposal of the maturity model in this study. Adapting de Bruin et al.'s (2005) definition of maturity models, the maturity model for the sustainable development of LSPs presented in Table 4 describes the extent to which a particular energy efficiency process, service or action is performed in their organisations.

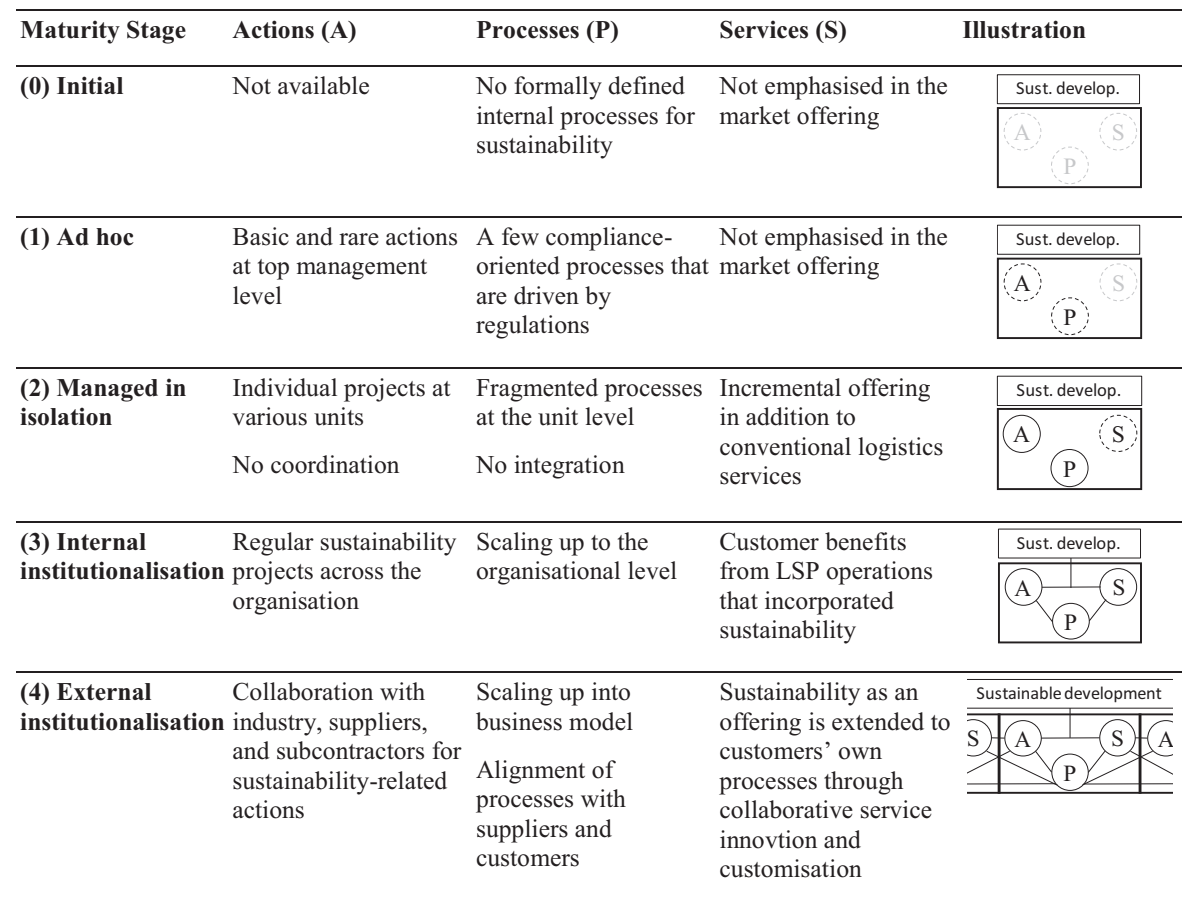

Table 4.

Maturity model for the sustainable development of LSPs

Note(s): Detailed analysis of the maturity model is provided in Appendix 
The five stages in the vertical dimension of the model capture levels of the institutionalisation of the three building blocks. Similar to Cagnin et al.'s (2005) business sustainability maturity model, the transition ranges from $a d$ hoc status to external integration at the network level. In an entirely discrete state, the transitions become integrated with external networks as LSPs advance in their sustainable development. Such an approach, extending what Evangelista (2014) has called point initiatives and supply chain initiatives, describes the transition from certain points in supply chains to application throughout the chain. The dimensions by which maturity differs can comprise energy management guides (Antunes et al., 2014), the context (Machado et al., 2017) and different organisational strategies for sustainability (Baumgartner and Ebner, 2010). To substantiate the model with empirical evidence, the horizontal dimension in Table 4 includes three building blocks - processes, services and actions - that illustrate activities undertaken at different stages of maturity. A detailed analysis of the maturity model with interlinkages identified between the findings and stages of maturity appears in Appendixes 1 and 2.

Stage 0: At the baseline stage, no observable actions, processes or services for environmental sustainability are present. In their maturity model concerning energy management, Introna et al. (2014) propose that organisations at the baseline stage are not interested in energy efficiency, energy performance is not measured and no signals from top management indicate the issue's existence. At that stage, LSPs exhibit similar characteristics and show no interest in energy efficiency or environmental sustainability in the form of actions performed by them, formalised processes or customer services.

Stage 1: The next stage is characterised by compliance and conformity with regulations, in a phase similar to the one described by Machado et al. (2017). In this stage, LSPs have recently begun to be exposed to regulations concerning energy mapping and decarbonisation (e.g. Swedish law, 2014, p. 266). To address those regulations, they undertake some sustainability-oriented initiatives, albeit somewhat minor ones, which are mostly segregated from the rest of the organisation and not formalised. The measurement approaches are poorly disseminated, existing KPIs are vague, and data collection is not continuous but highly fragmented. Attempts for certification by management systems are made during the stage, but the supporting processual structure is not yet established.

Stage 2: The subsequent stage captures what Introna et al. (2014) have labelled as being "By projects" or what Cagnin et al. (2005) have labelled as being "managed with no integration". At Stage 2, environmental sustainability is recognised, and some actions, processes and services are observed within the organisation; however, they are mostly isolated and not integrated with other functions. Mostly driven by functional managers who are keen on environmental sustainability, they receive symbolic support from top management. Sustainable logistics services or services addressing energy efficiency compose an alternative line of solutions offered in addition to existing conventional ones.

Stages 3 and 4 represent institutionalisation similar to the fourth to sixth stages in Reefke et al.'s (2014) model. In our model, however, institutionalisation occurs first internally (Stage 3), after which it extends to the external network (Stage 4). At Stage 3, environmental sustainability initiatives are scaled up to the organisational level, and collaboration between different units and top management is achieved. Environmental sustainability is not an incremental offering on top of existing offerings but an attribute integrated into all services provided. Energy mapping, conducted in an integrative fashion, underscores the energy efficiency of internal operations in relation to each other. Holistic communication strategies regarding sustainability and energy efficiency are established to involve all organisational members in the transition to environmental sustainability.

Once internal institutionalisation is realised, transition is scaled up to the external network. Cagnin et al. (2005) have labelled that system the "sustainability net", defined as the network of stakeholders who collaborate to produce, deliver and receive the value of sustainability at the final stage of the model. In our model, the network is a combination of
LSPs' energy efficiency 
both upstream and downstream members in the supply chains within which LSPs operate. In that sense, environmental sustainability is incorporated into the business model and integrated into the external networks in which the organisation operates. LSPs commence collaborating with suppliers, customers and subcontractors to facilitate new sustainabilityoriented actions, align sustainable processes and offer new sustainable services. Abbasi and Nilsson (2016) have also shown that taking the perspective of the supply or value chain is an activity that LSPs undertake for future sustainable development.

\section{Conclusion and implications}

This article provides a framework for understanding the sustainable development of LSPs according to their energy efficiency initiatives. In addition to analysing the framework's three building blocks - processes, services and actions - we have revealed insights into the depth of internal LSP processes, the bridging role of LSPs' energy efficiency-oriented services for customers and the variety of their initiatives in relation to their activity segments. Moreover, we have proposed a maturity model that conceptualises how the gradual change to a state of sustainability occurs at LSPs.

The findings suggest that LSPs are at the early stages of maturing towards general sustainability although their maturity may vary in the framework's building block of processes. In particular, the depth of processes discussed herein offers an opportunity for LSPs to align their internal initiatives towards energy efficiency with the operations of their customers, both in setting requirements for sustainable solutions and in overcoming challenges to their energy efficiency, namely specific needs that require customised solutions (e.g. flexibility in delivery). The bridging role of services between LSPs and customers, by comparison, provide opportunities for LSPs to trigger the demand for sustainable logistics services that previous research (e.g. Martinsen and Björklund, 2012; Bask and Rajahonka, 2017) indicates are lacking. Those sustainable services not only create additional value in the market but also bridge internal processes in which LSPs can achieve a certain depth that allows advancing the sustainability-oriented value offered by LSPs. By leveraging those advanced internal capabilities, LSPs can provide services that improve energy efficiency, which will consequently have positive economic outputs and can be expected to stimulate demand amongst logistics customers. Having the structure of a maturity model allows managers to monitor and evaluate the different stages of sustainable development at LSPs. As the internal process deepens, new sustainable services can be developed that, in turn, provide a higher degree of external institutionalisation for LSPs. The stages of the maturity model thus support a systematic evaluation of stand-alone initiatives that emerge in an ad hoc manner and pave the way for their institutionalisation. Moreover, considering that many manufacturing companies are now familiar with maturity models, having a similar approach at their logistics providers would aid supplier selection and performance evaluation for those organisations.

The study is not without its limitations. Although the study contributes to the literature by proposing a maturity model for the sustainable development of LSPs using the empirical data, the model requires further testing and refinement. In the future, researchers can use the model as a basis to test, revise, expand and refine it with the help of expert panels, especially by applying it to LSPs or by integrating it with quantitative assessments of maturity in sustainability. Moreover, researchers may use the framework to extend the list of actions, processes and services of LSPs that support their sustainable development. Further research is also needed to understand the interdependency between the three building blocks in the maturity model, particularly how actions and processes create favourable conditions for LSPs to advance their service offerings. In addition, conducting an in-depth analysis of different companies using the maturity model might provide insights into the different levels 
of maturity with respect to the individual building blocks. After all, an LSP's processes may be at the stage of external institutionalisation, whereas its services are only at the initial stage. For a more generalisable analysis, the items in the maturity model could provide the basis for a survey of a large sample of LSPs that would consequently afford an understanding of the general status of sustainable development in the logistics industry. Last, comparing the literature on energy efficiency, sustainability and operations management to refine the model for service organisations such as LSPs may indicate fruitful avenues for future research.

\section{Note}

1. Sustainable development of LSPs, in this manuscript, refers to the environmental dimension of sustainability.

\section{References}

Abareshi, A. and Molla, A. (2013), "Greening logistics and its impact on environmental performance: an absorptive capacity perspective", International Journal of Logistics: Research and Application, Vol. 16 No. 3, pp. 209-226, doi: 10.1080/13675567.2013.812193.

Abbasi, M. and Nilsson, F. (2016), "Developing environmentally sustainable logistics: exploring themes and challenges from a logistics service providers' perspective", Transportation Research Part D: Transport and Environment, Vol. 46, pp. 273-283, doi: 10.1016/j.trd.2016.04.004.

Abreu, M.F., Alves, A.C. and Moreira, F. (2017), "Lean-Green models for eco-efficient and sustainable production”, Energy, Vol. 137, pp. 846-853, doi: 10.1016/j.energy.2017.04.016.

Antunes, P., Carreira, P. and Mira da Silva, M. (2014), "Towards an energy management maturity model”, Energy Policy, Vol. 73, pp. 803-814, doi: 10.1016/j.enpol.2014.06.011.

Banoun, A., Dufour, L. and Andiappan, M. (2016), "Evolution of a service ecosystem: longitudinal evidence from multiple shared services centers based on the economies of worth framework", Journal of Business Research, Vol. 69 No. 8, pp. 2990-2998, doi: 10.1016/j.jbusres.2016.02.032.

Bask, A. and Rajahonka, M. (2017), "The role of environmental sustainability in the freight transport mode choice", International Journal of Physical Distribution and Logistics Management, Vol. 47 No. 7, pp. 560-602, doi: 10.1108/IJPDLM-03-2017-0127.

Baumgartner, R.J. and Ebner, D. (2010), "Corporate sustainability strategies: sustainability profiles and maturity levels", Sustainable Development, Vol. 18 No. 2, pp. 76-89, doi: 10.1002/sd.447.

Baumgartner, M., Léonardi, J. and Krusch, O. (2008), "Improving computerized routing and scheduling and vehicle telematics: a qualitative survey", Transportation Research Part D: Transport and Environment, Vol. 13 No. 6, pp. 377-382, doi: 10.1016/j.trd.2008.06.001.

Becker, J., Knackstedt, R. and Pöppelbuß, J. (2009), "Developing maturity models for IT management”, Business and Information Systems Engineering, Vol. 1 No. 3, pp. 213-222, doi: 10.1007/s12599009-0044-5.

Brockhaus, S., Kersten, W. and Knemeyer, A.M. (2013), "Where do we go from here? Progressing sustainability implementation efforts across supply chains", Journal of Business Logistics, Vol. 34 No. 2, pp. 167-182.

Browne, M. (2005), "Special issue introduction: transport energy use and sustainability", Transport Reviews, Vol. 25 No. 6, pp. 643-645, doi: 10.1080/01441640500422140.

Brundtland, G.H. (1987), "Report of the World Commission on environment and development: our common future", available at: https://sustainabledevelopment.un.org/content/documents/ 5987our-common-future.pdf (accessed 10 October 2019).

Bryman, A. and Bell, E. (2011), Business Research Methods, 3rd ed., Oxford University Press, Oxford.

Busse, C. and Wallenburg, C.M. (2011), "Innovation management of logistics service providers: foundations, review and research agenda", International Journal of Physical Distribution and Logistics Management, Vol. 41 No. 2, pp. 187-218, doi: 10.1108/09600031111118558. 
Cagnin, C.M., Loveridge, D. and Jeff, B. (2005), "Business sustainability maturity model", Business Strategy and the Environment Conference, Leeds, September 4-6, pp. 4-6.

Centobelli, P., Cerchione, R. and Esposito, E. (2017a), "Developing the WH2 framework for environmental sustainability in logistics service providers: a taxonomy of green initiatives", Journal of Cleaner Production, Vol. 165, pp. 1063-1077, doi: 10.1016/j.jclepro.2017.07.150.

Centobelli, P., Cerchione, R. and Esposito, E. (2017b), "Environmental sustainability in the service industry of transportation and logistics service providers: systematic literature review and research directions", Transportation Research Part D: Transport and Environment, Vol. 53, pp. 454-470, doi: 10.1016/j.trd.2017.04.032.

Centobelli, P., Cerchione, R. and Esposito, E. (2020), "Evaluating environmental sustainability strategies in freight transport and logistics industry", Business Strategy and the Environment, Vol. 29 No. 3, pp. 1563-1574.

Chiesa, V., Coughlan, P. and Voss, C.A. (1996), "Development of a technical innovation audit", Journal of Product Innovation Management, Vol. 13 No. 2, pp. 105-136, doi: 10.1111/1540-5885.1320105.

Colicchia, C., Marchet, G., Melacini, M. and Perotti, S. (2013), "Building environmental sustainability: empirical evidence from Logistics Service Providers", Journal of Cleaner Production, Vol. 59, pp. 197-209, doi: 10.1016/j.jclepro.2013.06.057.

Corbin, J. and Strauss, A. (2008), Techniques and Procedures for Developing Grounded Theory, 3rd ed., Sage, Thousand Oaks, CA.

Cunliffe, A.L. (2011), “Crafting qualitative research: Morgan and Smircich 30 years on”, Organizational Research Methods, Vol. 4 No. 4, pp. 647-673, doi: 10.1177/1094428110373658.

de Bruin, T., Freeze, R., Kaulkarni, U. and Rosemann, M. (2005), "Understanding the main phases of developing a maturity assessment model", Paper Presented at Australasian Conference on Information Systems (ACIS), Sydney, November 30 - December 2.

Diwekar, U. (2005), "Green process design, industrial ecology, and sustainability: a systems analysis perspective", Resources, Conservation and Recycling, Vol. 44 No. 3, pp. 215-235, doi: 10.1016/j. resconrec.2005.01.007.

Edmondson, A.C. and McManus, S.E. (2007), "Methodological fit in management field research", Academy of Management Review, Vol. 32 No. 4, pp. 1246-1264.

Ellram, L. and Tate, W.L. (2015), "Redefining supply management's contribution in services sourcing", Journal of Purchasing and Supply Management, Vol. 21 No. 1, pp. 64-78, doi: 10.1016/j.pursup. 2014.10.001.

European Union (2018), "Directive (EU) 2018/2002 of the European parliament and the council of 11 December 2018 amending directive 2012/27/EU on energy efficiency", available at: https://eurlex.europa.eu/legal-content/EN/TXT/PDF/?uri=CELEX:32018L2002\&from=EN (accessed 12 November 2018).

Evangelista, P. (2014), "Environmental sustainability practices in the transport and logistics service industry: an exploratory case study investigation", Research in Transportation Business and Management, Vol. 12, pp. 63-72, doi: 10.1016/j.rtbm.2014.10.002.

Evangelista, P., Santoro, L. and Thomas, A. (2018), "Environmental sustainability in third-party logistics service providers: a systematic literature review from 2000-2016", Sustainability, Vol. 10 No. 5, p. 1627, doi: 10.3390/su10051627.leo.

Fawcett, S.E., Waller, M.A., Miller, J.W., Schwieterman, M., Hazen, B. and Overstreet, R. (2014), “A trail guide to publishing success: tips on writing influential conceptual, qualitative, and survey research", Journal of Business Logistics, Vol. 35 No. 1, pp. 1-16, doi: 10.1111/jbl.12039.

Flick, U. (2014), An Introduction to Qualitative Research, 5th ed., SAGE, London.

Franklin, J.R. (2008), "Managing the Messy process of logistics service innovation", in Wagner, S.M. and Busse, C. (Eds), Managing Innovation - The New Competitive Edge for Logistics Service Providers, 1st ed., Haupt Verlag, Berne, pp. 153-170. 
Gammelgaard, B. and Prockl, G. (2012), "Innovating for green supply chain management: the logistics service providers perspective", in Carlsson, C.-M., Emtairah, T., Gammelgaard, B., Jensen, A.V. and Thidell, A. (Eds), Rethinking Transport in the Öresund Region: Policies, Strategies and Behaviours, pp. 165-182, Chapter 10.

Geary, S., Childerhouse, P. and Towill, D.R. (2002), "Uncertainty and the seamless supply chain", Supply Chain Management Review, Vol. 6 No. 4, pp. 52-61.

Golicic, S., Boerstler, C. and Ellram, L. (2010), "Greening' the transportation in your supply chain", MIT Sloan Management Review, Vol. 51 No. 2, pp. 47-55.

Halldórsson, Á. and Aastrup, J. (2003), "Quality criteria for qualitative inquiries in logistics”, European Journal of Operational Research, Vol. 144 No. 2, pp. 321-332, doi: 10.1016/S0377-2217(02)00397-1.

Halldórsson, Á. and Altuntas Vural, C. (2019), "Servitization and logistics: building a service-based typology", 26th Annual Euroma Conference, Helsinki, June 2019.

Halldórsson, Á. and Kovács, G. (2010), "The sustainable agenda and energy efficiency", International Journal of Physical Distribution and Logistics Management, Vol. 40 Nos 1-2, pp. 5-13.

Halldórsson, Á., Gremyr, I., Winter, A. and Taghahvi, N. (2018), "Lean energy: turning sustainable development into organizational renewal”, Sustainability, Vol. 10 No. 12, p. 4464, doi: 10.3390/ su10124464.

Halldórsson, Á., Altuntas Vural, C. and Wehner, J. (2019a), "Logistics service triad for household waste: consumers as co-producers of sustainability", International Journal of Physical Distribution and Logistics Management, Vol. 49 No. 4, pp. 398-415, doi: 10.1108/IJPDLM-022019-0065.

Halldórsson, Á., Sundgren, C. and Wehner, J. (2019b), "Sustainable supply chains and Energy: where 'planet' meets 'profit”, in Sarkis, J. (Ed.), Handbook on Sustainable Supply Chains, Edward Elgar Publishers, Cheltenham.

Hynds, E.J., Brandt, V., Burek, S., Jager, W., Knox, P., Parker, J.P., Schwartz, L., Taylor, J. and Zietlow, M. (2014), "A maturity model for sustainability in new product development", Research-Technology Management, Vol. 57 No. 1, pp. 50-57. doi: 10.5437/08956308X5701143.

Introna, V., Cesarotti, V., Benedetti, M., Biagiotti, S. and Rotunno, R. (2014), "Energy Management Maturity Model: an organizational tool to foster the continuous reduction of energy consumption in companies", Journal of Cleaner Production, Vol. 83, pp. 108-117, doi: 10.1016/ j.jclepro.2014.07.001.

Isaksson, K. and Huge-Brodin, M. (2013), "Understanding efficiencies behind logistics service providers' green offerings”, Management Research Review, Vol. 36 No. 3, pp. 216-238, doi: 10. 1108/01409171311306382.

Kalenoja, H., Kallionpää, E. and Rantala, J. (2011), "Indicators of energy efficiency of supply chains", International Journal of Logistics: Research and Applications, Vol. 14 No. 2, pp. 77-95.

Laari, S., Töyli, J. and Ojala, L. (2018), "The effect of a competitive strategy and green supply chain management on the financial and environmental performance of logistics service providers", Business Strategy and the Environment, Vol. 27 No. 7, pp. 872-883.

Lam, J.S.L. and Dai, J. (2015), "Environmental sustainability of logistics service provider: an ANP-QFD approach”, International Journal of Logistics Management, Vol. 26 No. 2, pp. 313-333, doi: 10. 1108/IJLM-08-2013-0088.

Léonardi, J. and Baumgartner, M. (2004), "CO2 efficiency in road freight transportation: status quo, measures and potential", Transportation Research Part D: Transport and Environment, Vol. 9 No. 6, pp. 451-464, doi: 10.1016/j.trd.2004.08.004.

Lieb, R.C. and Lieb, K.J. (2010a), "The North American third-party logistics industry in 2008: the provider CEO perspective", Transportation Journal, Vol. 49 No. 2, pp. 53-65.

Lieb, K. and Lieb, R. (2010b), "Environmental sustainability in the third-party logistics (3PL) industry", International Journal of Physical Distribution and Logistics Management, Vol. 40 No. 7, pp. 524-533, doi: $10.1108 / 09600031011071984$. 
Liimatainen, H., Stenholm, P., Tapio, P. and Mckinnon, A. (2012), "Energy efficiency practices among road freight hauliers", Energy Policy, Vol. 50, pp. 833-842, doi: 10.1016/j.enpol.2012.08.049.

Liimatainen, H., Nykänen, L., Arvidsson, N., Hovi, I., Jensen, T. and Østli, V. (2014), "Energy efficiency of road freight hauliers—a Nordic comparison”, Energy Policy, Vol. 67, pp. 378-387, doi: 10.1016/ j.enpol.2013.11.074.

Liljestrand, K., Christopher, M. and Andersson, D. (2015), "Using a transport portfolio framework to reduce carbon footprint", International Journal of Logistics Management, Vol. 26 No. 2, pp. 296-312, doi: 10.1108/IJLM-06-2013-0073.

Machado, C.G., de Lima, E.P., da Costa, S.E.G., Angelis, J.J. and Mattioda, R.A. (2017), "Framing maturity based on sustainable operations management principles", International Journal of Production Economics, Vol. 190, pp. 3-21, doi: 10.1016/j.jpe.2017.01.020.

Martinsen, U. and Björklund, M. (2012), "Matches and gaps in the green logistics market", International Journal of Physical Distribution and Logistics Management, Vol. 42 No. 6, pp. 562-583, doi: 10.1108/09600031211250596.

Martinsen, U. and Huge-Brodin, M. (2014), "Environmental practices as offerings and requirements on the logistics market”, Logistics Research, Vol. 7 No. 1, pp. 1-22, doi: 10.1007/s12159-014-0115-y.

McKinnon, A.C. (2012), "Reducing energy consumption and emissions in the logistics sector", in Energy, Transport, and the Environment, Springer, London, pp. 521-537.

Miles, M.B., Huberman, A.M. and Saldana, J. (2020), Qualitative Data Analysis: A Methods Sourcebook, Sage, Los Angeles, CA.

Multaharju, S., Lintukangas, K., Hallikas, J. and Kähkönen, A. (2017), "Sustainability-related risk management in buying logistics services: an exploratory cross-case analysis", International Journal of Logistics Management, Vol. 28 No. 4, pp. 1351-1367, doi: 10.1108/IJLM-05-2016-0134.

Nilsson, F.R., Sternberg, H. and Klaas-Wissing, T. (2017), "Who controls transport emissions and who cares? Investigating the monitoring of environmental sustainability from a logistics service provider's perspective", International Journal of Logistics Management, Vol. 28 No. 3, pp. 798-820, doi: 10.1108/IJLM-11-2015-0197.

Oberhofer, P. and Dieplinger, M. (2014), "Sustainability in the transport and logistics sector: lacking environmental measures", Business Strategy and the Environment, Vol. 23 No. 4, pp. 236-253, doi: 10.1002/bse.1769.

Perotti, S., Zorzini, M., Cagno, E. and Micheli, G.J. (2012), “Green supply chain practices and company performance: the case of 3PLs in Italy", International Journal of Physical Distribution and Logistics Management, Vol. 42 No. 7, pp. 640-672, doi: 10.1108/09600031211258138.

Piecyk, M.I. and Björklund, M. (2015), "Logistics service providers and corporate social responsibility: sustainability reporting in the logistics industry", International Journal of Physical Distribution and Logistics Management, Vol. 45 No. 5, pp. 459-485, doi: 10.1108/IJPDLM-08-2013-0228.

Pieters, R., Glöckner, H.H., Omta, S.W.F. and Weijers, S. (2012), "Dutch logistics service providers and sustainable physical distribution: searching for focus", International Food and Agribusiness Management Review, Vol. 15 No. B, pp. 107-126.

Prajogo, D., Tang, K.Y.A. and Lai, K.-H. (2014), "The diffusion of environmental management system and its effect on environmental management practices", International Journal of Operations and Production Management, Vol. 34 No. 5, pp. 565-585, doi: 10.1108/IJOPM-10-2012-0448.

Pratt, M.G. (2008), "Fitting oval pegs into round holes: tensions in evaluating and publishing qualitative research in top-tier", North American Journals, Organizational Research Methods, Vol. 11 No. 3, pp. 481-509, doi: 10.1177/1094428107303349.

Punte, S., Tavasszy, L., Baeyens, A. and Liesa, F. (2019), "A framework and process for the development of a roadmap towards zero emissions logistics 2050", in Alliance for Logistics Innovation Through Collaboration in Europe, available at: http://www.etp-logistics.eu/wpcontent/uploads/2019/12/Alice-Zero-Emissions-Logistics-2050-Roadmap-WEB.pdf (accessed 12 August 2020). 
Reefke, H., Ahmed, M.D. and Sundaram, D. (2014), "Sustainable supply chain management—decision making and support: the SSCM maturity model and system", Global Business Review, Vol. 15 No. 4_suppl, pp. 1S-12S, doi: 10.1177/0972150914550138.

Reinerth, D., Busse, C. and Wagner, S.M. (2018), "Using country sustainability risk to inform sustainable supply chain management: a design science study", Journal of Business Logistics, Vol. 40 No. 3, pp. 241-264.

Robèrt, K.H., Schmidt-Bleek, B., Aloisi de Larderel, J., Basile, G., Jansen, J.L., Kuehr, R., Thomas, P.P., Suzuki, M., Hawken, P. and Wackernagel, M. (2002), "Strategic sustainable developmentselection, design and synergies of applied tools", Journal of Cleaner Production, Vol. 10 No. 3, pp. 197-214, doi: 10.1016/S0959-6526(01)00061-0.

Roth, A. and Kåberger, T. (2002), "Making transport systems sustainable", Journal of Cleaner Production, Vol. 10 No. 4, pp. 361-371, doi: 10.1016/S0959-6526(01)00052-X.

Sarkis, J. (2003), “A strategic decision framework for green supply chain management”, Journal of Cleaner Production, Vol. 11 No. 4, pp. 397-409, doi: 10.1016/S0959-6526(02)00062-8.

Schulze, M., Nehler, H., Ottosson, M. and Thollander, P. (2016), "Energy management in industry - a systematic review of previous findings and an integrative conceptual framework", Journal of Cleaner Production, Vol. 112 No. Part 5, pp. 3692-3708, doi: 10.1016/j.jclepro.2015.06.060.eu.

Seuring, S. and Müller, M. (2008), "From a literature review to a conceptual framework for sustainable supply chain management", Journal of Cleaner Production, Vol. 16 No. 15, pp. 1699-1710, doi: 10. 1016/j.jclepro.2008.04.020.

Swedish law (2014), 266, "Lag om energikartläggning i stora företag, [in English] Law on energy mapping in large companies", available at: https:/www.global-regulation.com/translation/ sweden/2987509/law-\%25282014\%253a266\%2529-on-energy-audits-in-large-enterprises.html (accessed 12 November 2018).

Tacken, J., Sanchez Rodrigues, V. and Mason, R. (2014), "Examining CO2e reduction within the German logistics sector", International Journal of Logistics Management, Vol. 25 No. 1, pp. 54-84, doi: 10.1108/IJLM-09-2011-0073.

Taptich, M.N., Horwath, A. and Chester, M.V. (2016), "Worldwide greenhouse gas reduction potentials in transportation by 2050", Journal of Industrial Ecology, Vol. 20 No. 2, pp. 329-340.

United Nations (2015), "About the sustainability goals [online]", available at: https://www.un.org/ sustainabledevelopment/sustainable-development-goals/ (accessed 16 April 2019).

Vujanović, D., Mijailović, R., Momčilović, V. and Papić, V. (2010), "Energy efficiency as a criterion in the vehicle fleet management process", Thermal Science, Vol. 14 No. 4, pp. 865-878, doi: 10.2298/ tsci090719010v.

Wendler, R. (2012), "The maturity of maturity model research: a systematic mapping study", Information and Software Technology, Vol. 54 No. 12, pp. 1317-1339, doi: 10.1016/j.infsof.2012. 07.007 .

Wolf, C. and Seuring, S. (2010), "Environmental impacts as buying criteria for third party logistical services", International Journal of Physical Distribution and Logistics Management, Vol. 40 Nos 1/2, pp. 84-102, doi: 10.1108/09600031011020377. 


\section{Appendix 1}

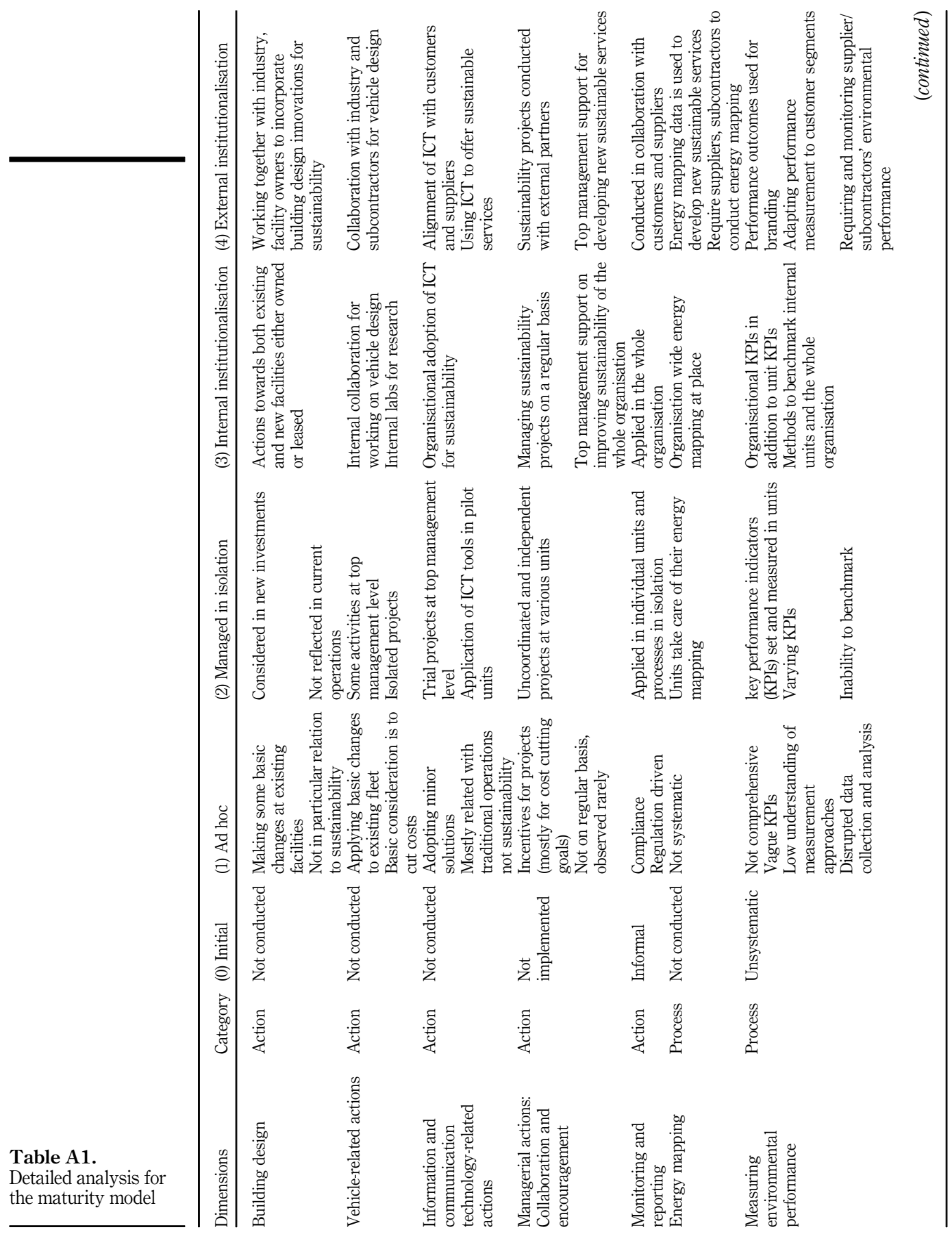




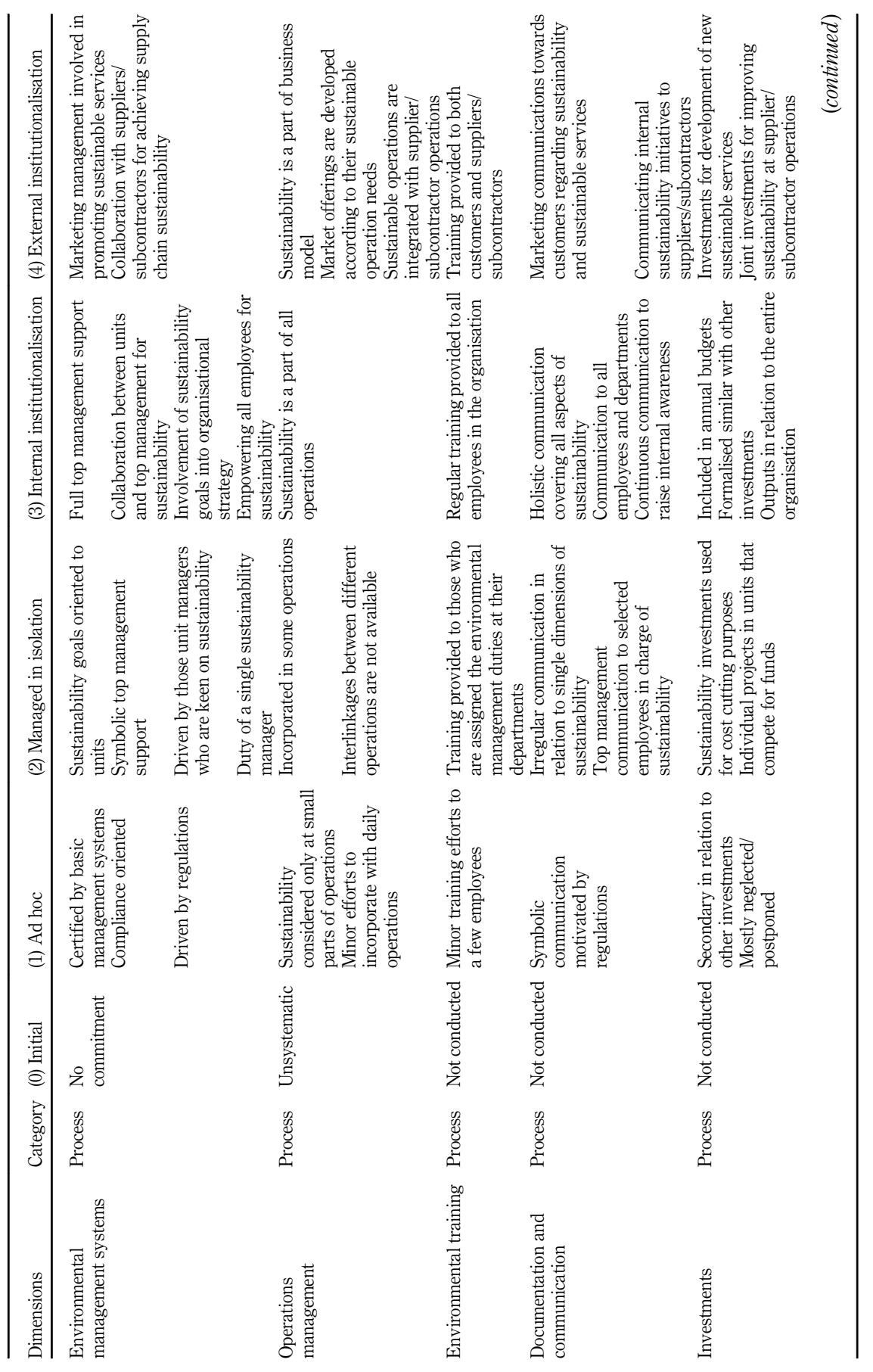

LSPs' energy efficiency 


\section{IJLM}

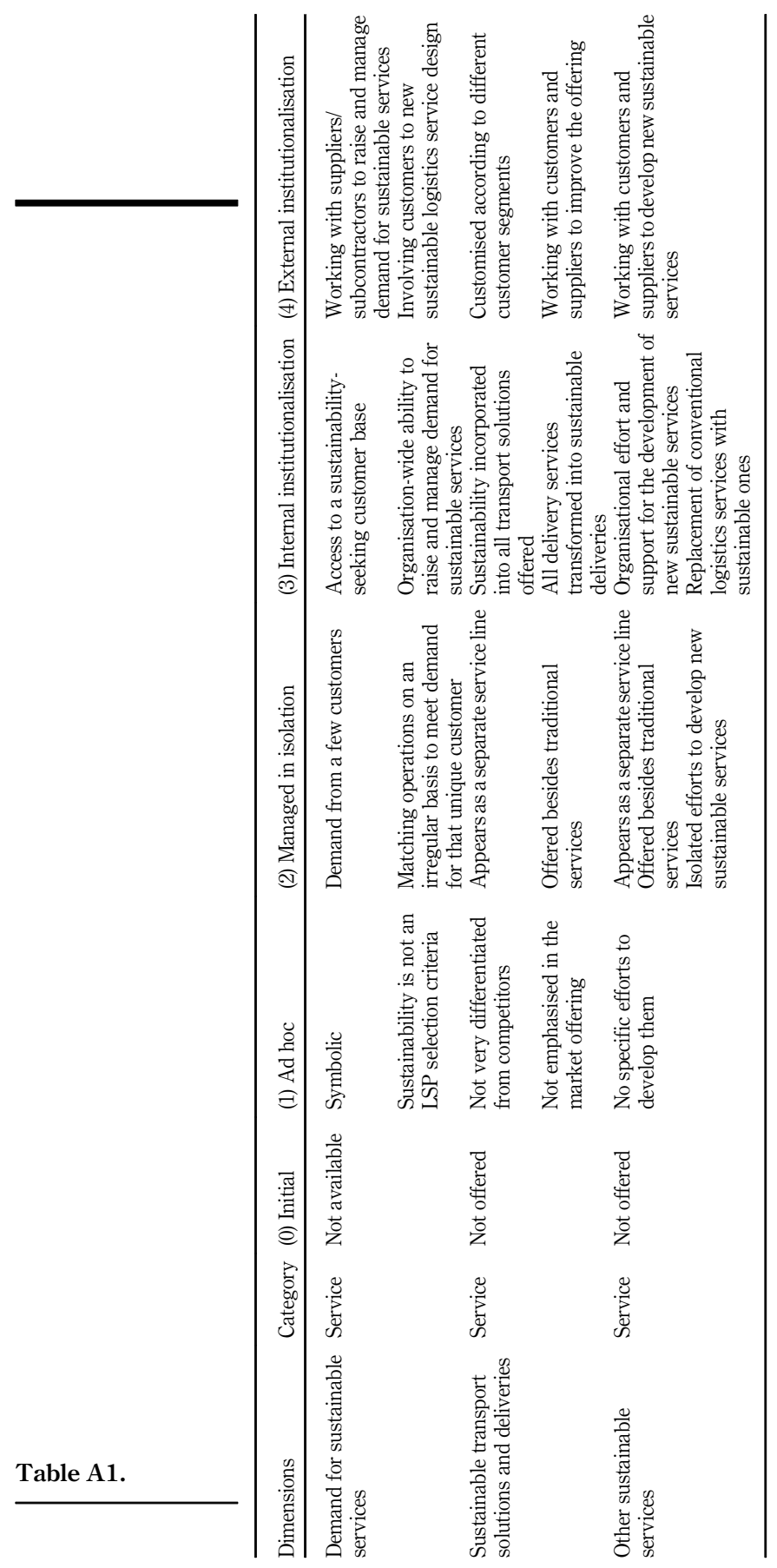




\section{Appendix 2}

Interview guide 1

$\mathrm{Nr}$. Categories

1 Introductory questions

2 Strategic management decision

$3 \quad$ Energy audit

$4 \quad$ Strategy/planning

5 Implementation/operation

$6 \quad$ Controlling

$7 \quad$ Organisation

$8 \quad$ Culture

$9-\mathrm{END}$
Questions

1.1 Directed to each interviewee and company individually

1.2 What does energy efficiency mean in your organization?

2.1 What are the driving forces for energy efficiency improvements?

2.2 How does energy efficiency improvements get initiated in your company?

3.1 How long have you conduct energy mapping?

3.2 Who conducts the energy mapping?

3.3 Are there other ways to identify the potential for energy efficiency improvements?

4.1 Do you have a written energy or sustainability policy/strategy?

4.2 What are your goals in regard to energy efficiency?

4.3 Who sets the goals?

4.4 What is the coverage of your goal (e.g. energy consumption, $\mathrm{CO}_{2}$ emissions, and greenhouse gas emissions)?

4.5 Do you develop a strategic action plan to reach the goals?

4.6 Do you assess risks in your energy efficiency improvement process? What for risks?

5.1 Do you change technologies in order to reach energy efficiency (e.g. change of vehicle fleet, use of ICT)?

5.2 How do you evaluate after the energy mapping which improvement potential should be prioritized and which measure implemented?

5.3 Who makes the decision which energy efficiency measures should be implemented?

5.4 How are the energy efficiency measures financed and budgeted?

5.5 What is the time horizon for energy efficiency investments and returns?

6.1 Do you use an Energy Management System (EMS) for monitoring energy efficiency (e.g. ISO)?

6.2 What are the KPIs for energy monitoring?

6.3 How and how often do you collect data on energy monitoring?

6.4 What is the data on energy monitoring used for (external reporting, internal reporting etc.)?

6.5 Do you do any benchmarking with other companies or internally?

7.1 Do you have an energy manager or responsible?

7.2 Where in the organizational structure is this manager located (e.g. close to the management level)?

8.1 How is the information on energy communicated to different levels in the organization?

8.2 How involved and committed is the top management with energy efficiency improvements?

8.3 Are there any incentives for employees to work with energy efficiency improvements?

8.4 Does the company work actively with engaging employees in energy efficiency improvements (e.g. education, newsletter)?

9.1 What are the main challenges/barriers to implement energy efficiency projects? How are they addressed in the company?

9.2 Is the process (by Schulze et al., 2016) valid for you?

9.3 What are your reflections after this interview - what questions or thoughts came to your mind?

Interview guide 2

\begin{tabular}{|c|c|c|}
\hline Categories & Code & Interview questions \\
\hline \multirow[t]{2}{*}{ Introduction } & 1.1 & directed to each interviewee and company individually \\
\hline & 1.2 & What is your environmental sustainability journey from the beginning? \\
\hline \multirow{14}{*}{$\begin{array}{l}\text { Efforts and } \\
\text { processes }\end{array}$} & $2.1 \mathrm{a}$ & What are the driving forces for improvements of environmental sustainability? \\
\hline & $2.1 \mathrm{~b}$ & What steps are you taking towards environmental sustainability? \\
\hline & 2.2 & How does those improvements get initiated in your company? \\
\hline & 3.1 & How long have you conduct energy mapping? \\
\hline & 3.2 & Who conducts the energy mapping? \\
\hline & 4.1 & Do you have a written energy or sustainability policy/strategy? \\
\hline & 4.2 & $\begin{array}{l}\text { What are your goals in regard to environmental sustainability and their coverage (e.g. energy } \\
\text { consumption, } \mathrm{CO} 2 \text { emissions, and greenhouse gas emissions)? }\end{array}$ \\
\hline & $5.1 \mathrm{a}$ & $\begin{array}{l}\text { Do you change technologies in order to reach environmental sustainability (e.g. change of vehicle fleet, } \\
\text { use of ICT)? }\end{array}$ \\
\hline & $5.1 \mathrm{~b}$ & What other improvement efforts are you taking towards sustainability? \\
\hline & 5.2 & How are the improvements of environmental sustainability financed and budgeted? \\
\hline & 6.1 & Do you use an Environmental/Energy Management System for monitoring energy efficiency (e.g. ISO)? \\
\hline & 6.2 & What are the KPIs for environmental sustainability monitoring? \\
\hline & 6.3 & $\begin{array}{l}\text { What is the data on environmental sustainability monitoring used for (external reporting, internal } \\
\text { reporting etc.)? }\end{array}$ \\
\hline & 6.4 & Do you do any benchmarking with other companies or internally? \\
\hline
\end{tabular}

(continued)

Table A2. Interview guides 


\begin{tabular}{|c|c|c|}
\hline $\begin{array}{l}\text { Interview guide } 2 \\
\text { Categories }\end{array}$ & Code & Interview questions \\
\hline \multirow[t]{4}{*}{ Organisation } & 7.1 & How is sustainability organized in your company (e.g. who is responsible for what)? \\
\hline & 8.1 & $\begin{array}{l}\text { How is the information on environmental sustainability communicated to different levels in the } \\
\text { organisation? }\end{array}$ \\
\hline & 8.2 & Are there any incentives for employees to work with environmental sustainability improvements? \\
\hline & 8.3 & $\begin{array}{l}\text { Does the company work actively with engaging employees in environmental sustainability } \\
\text { improvements (e.g. education, newsletter)? }\end{array}$ \\
\hline \multirow[t]{5}{*}{ Service } & $9.1 \mathrm{a}$ & Do you provide any green or sustainable services? \\
\hline & $9.1 \mathrm{~b}$ & What kind of sustainable services do you offer your customers (e.g. carbon calculation to customer)? \\
\hline & 9.2 & How do you offer your traditional logistics services in a sustainable way? \\
\hline & $9.3 \mathrm{a}$ & Are there specific sustainable services that your customer demand from you? \\
\hline & $9.3 \mathrm{~b}$ & Is there any other way, how you contribute to your customer's sustainability? \\
\hline \multirow[t]{2}{*}{$-E N D$} & 10.1 & $\begin{array}{l}\text { What are the main challenges/barriers to implement environmental sustainability projects? How are } \\
\text { they addressed in the company? }\end{array}$ \\
\hline & 10.2 & What are your reflections after this interview - what questions or thoughts came to your mind? \\
\hline
\end{tabular}

Table A2.

\begin{abstract}
About the authors
Jessica Wehner is a researcher in logistics and freight transport and currently works as a project manager at Chalmers Industriteknik in Gothenburg, Sweden. She received her $\mathrm{PhD}$ degree in January 2020 from Chalmers University of Technology, Sweden. She holds a master's degree in industrial engineering from TU Darmstadt, Germany. Her research relates to environmental sustainability and energy efficiency in supply chains and logistics systems.

Naghmeh Taghavi Nejad Deilami is a $\mathrm{PhD}$ candidate in service management and logistics at Chalmers University of Technology, Sweden. Her research relates sustainable development of operations. She holds a master's degree in quality and operations management from Chalmers University of Technology, Sweden. She is currently working as a senior scientist at AstraZeneca Early Product Development and Manufacturing in Gothenburg, Sweden.

Ceren Altuntas Vural is an Associate Professor at Chalmers University of Technology, Sweden. After having worked for transport and logistics industries from 2003 to 2009, she received her $\mathrm{PhD}$ degree from Dokuz Eylul University, Izmir, Turkey. Her research interests include container shipping, port management, logistics services and supply chain management, with a particular focus on sustainability and customer orientation. Ceren Altuntas Vural is the corresponding author and can be contacted at: ceren.altuntasvural@chalmers.se

Árni Halldórsson is a Professor in Supply Chain Management at Chalmers University of Technology, Sweden. He is also affiliated with Hanken School of Economics, Finland, within Supply Chain Management and Social Responsibility. His research relates to sustainable supply, service supply chains, inter-organisational relationships and energy efficiency in logistics.
\end{abstract}

For instructions on how to order reprints of this article, please visit our website:

www.emeraldgrouppublishing.com/licensing/reprints.htm

Or contact us for further details: permissions@emeraldinsight.com 